\title{
Efficiency of Dimethyl Sulphoxide and Ethylene Glycol on Subsequent Development of Vitrified Awassi Sheep Embryos
}

\author{
Mardenli $\mathrm{O}^{1}$, Mohammad $\mathrm{MS}^{2}$, Hassooni $\mathrm{HA}^{3}$ \\ ${ }^{1}$ Departement of Animal Production, Faculty of Agriculture, University of Aleppo, Syria \\ ${ }^{2}$ Departement of Animal Production, Faculty of Agriculture, University of Alqadisiah, Iraq \\ ${ }^{3}$ Departement of Animal Production, Faculty of Agriculture, University of Al-Muthanna, Iraq \\ E-mail: omardenli@gmail.com
}

(received 09-02-2020; revised: 05-03-2020; accepted: 05-03-2020)

\begin{abstract}
ABSTRAK
Mardenli O, Mohammad MS, Hassooni HA. 2020. Efisiensi dimetil sulfoksida dan etilena glikol pada perkembangan subsequen embrio domba Awassi yang divitrifikasi. JITV 25(2):60-67. DOI: http://dx.doi.org/10.14334/jitv.v25i2.2459

Penggunaan krioprotektan dalam vitrifikasi dapat menurunkan kerusakan embrio dan meningkatkan daya hidupnya. Penelitian ini dilakukan di laboratorium bioteknologi reproduksi Fakultas Pertanian Universitas Aleppo. Penelitian ini bertujuan untuk melihat efesiensi dimetil sulfoksida (DMSO) dan etilena glikol (EG) terhadap viabilitas dan daya hidup embrio muda domba Awassi Siria. Embrio divitrifisasi dalam tiga larutan krioprotektan: A. DMSO 3 ml, B. EG 3 ml dan C yang tersusun dari kombinasi DMSO $(1,5 \mathrm{ml})$ dan EG $(1,5 \mathrm{ml})$. Setelah proses thawing, embrio yang telah divitrifikasi dalam larutan $\mathrm{C}$ memiliki tingkat pembelahan paling tinggi $(\mathrm{P}<0,01)$ dibandingkan pada larutan $\mathrm{A}$ dan $\mathrm{B}$ secara berturut-turut untuk tahap 2-16 pembelahan sel (50,00\% Vs 30,77\% dan 36,36\%); morula (9,00\% Vs 44,44\% dan 40,00\%); dan blastosis (92,86\% Vs 58,33\% dan 50,00\%). Pada tahap blastosis, tahap 2-16 pembelahan sel embrio yang telah divitrifikasi dalam larutan C memiliki tingkat kekuatan dibandingkan dalam larutan A dan B secara berturut-turut sebesar 39,20\% Vs 23,08\% dan 22,73\%. Jumlah embrio tertahan menurun secara signifikan $(\mathrm{P}<0,05)$ setelah proses pencairan dalam 3 larutan tertama tahap morula dan blastosis secara berturut-turut sebesar 0,00 dan 3,70\% respectively (larutan C). Tidak terdapat perbedaan yang signifikan yang terlihat pada ketiga tipe embrio dalam semua tahap dan larutan meskipun terlihat rentang jarak yang luas. Hal ini menunjukkan maksimum penggunaan larutan campuran DMSO dan EG yang dianjurkan untuk hasil yang baik adalah 1:1 dalam proses vitrifikasi embrio domba.
\end{abstract}

Kata Kunci: Domba Awassi, Dimetil Sulfoksida, Etilena Glikol, Produksi Embrio In Vitro, Vitrifikasi

\section{ABSTRACT}

Mardenli O, Mohammad MS, Hassooni HA. 2020. Efficiency of dimethyl sulphoxide and ethylene glycol on subsequent development of vitrified Awassi sheep embryos. JITV 25(2):60-67. DOI: http://dx.doi.org/10.14334/jitv.v25i2.2459

The use of cryoprotectants in vitrification would reduce the critical damages to the embryos, thus increase the survival rates. This research was conducted in the laboratory of reproductive biotechnology at the faculty of Agriculture of Aleppo University. The study aimed to evaluate the viability and survivability of early Syrian Awassi embryos under the influence of dimethyl sulphoxide (DMSO) and ethylene glycol (EG) following vitrification. Embryos were vitrified in three solutions of cryoprotectants (A: DMSO (3 ml), B: EG (3 ml), and C which was composed of a combination of DMSO (1.5 ml) and EG (1.5 $\mathrm{ml})$ ). After thawing, embryos that had been vitrified in $\mathrm{C}$ solution achieved the highest rates of cleavage $(\mathrm{P}<0.01)$ comparing with A and B solutions for 2-16 cell stage (50.00\% Vs $30.77 \%$ and $36.36 \%$ ), morula $(9.00 \%$ Vs $44.44 \%$ and $40.00 \%)$ and blastocyst stage embryos (92.86\% Vs 58.33\% and 50.00\%) respectively. Down to the hatching blastocyst stage, 2-16 cell stage vitrified embryos in $\mathrm{C}$ solution achieved an encouraging rate comparing with A and B solutions $(39.20 \% \mathrm{Vs} 23.08 \%$ and $22.73 \%$ respectively). The rates of arrested embryos decreased significantly $(\mathrm{P}<0.05)$ after thawing across the three solutions especially the morula and blastocyst stage ( 0.00 and $3.70 \%$ respectively) (C solution). No significant differences were observed in the three types of embryos across all stages and solutions despite the large range among these rates. Given the apparent benefit of the participatory effect of cytoprotectants, it is advised to use a mixture of DMSO and EG (1:1) in vitrification of ovine embryos.

Key Words: Awassi Sheeep, Dimethyl Sulphoxide, Ethylene Glycol, In Vitro Embryo Production, Vitrification

\section{INTRODUCTION}

Recently, cryobiology is considered the most important science in embryo technology, especially the In Vitro Embryo Production applications (IVEP).
Despite the great progress achieved by this technology in the field of farm animal industry, there are still some outstanding issues that need solutions. In order to preserve the embryos produced In vitro, it was necessary to face many prominent obstacles, the most 
important of which is the decrease in the survivability rates of frozen embryos during the blastomere stage, also, the high accumulated content of lipids (especially triacylglycerides) in embryonic cells, which have harmful effects (Palasz et al. 2008). There are two methods in the cryopreservation of embryo: vitrification and programmed slow freezing (Arav 2014). In literature, some considerations were identified in the programmed slow freezing, Thompson et al. (2011) indicated that subjecting embryos to a rate of $1{ }^{\circ} \mathrm{C} \mathrm{min}$ is considered a typical cooling rate for mammalian embryos. Despite the huge costs, equipment, and multiple steps of slow freezing, it has been observed a decrease in both survival and implantation rates (Bromfield et al. 2009).

Vitrification method depends basically on the use of high concentrations of cryoprotectants and the very fast freezing rates (Moussa et al. 2014). Due to the chemical and molecular properties of DMSO and EG, the use of these two compounds as cryoprotectants agents (CPAs) has prevailed in vitrification strategy, The prominent role of DMSO is in reducing the electrolytic concentration in the residual chilled contents within and around of a biological cell, on the other hand, EG alters the hydrogen bonding while mixing it with water during cryopreservation (Bhattacharya 2018). Within the vitrification scenario, the toxic effects of the cryoprotectants were not neglected, as both DMSO and EG are characterized by the minimal toxic effect (Best 2015). However, as for all cell lines, the cytotoxicity of DMSO could increase at a high concentration of this agent (Fahy 2010).

Therefore, the present study was designed to evaluate the efficiency of the cryoprotectants levels (DMSO, EG, and combination of DMSO and EG 1:1) that used in vitrification methods on morphological survival and subsequent development of Awassi sheep early embryos produced in vitro following vitrification.

\section{MATERIALS AND METHODS}

\section{Animal, and oocyte recovery}

Ovaries of Awassi ewes were collected from a local slaughterhouse in Aleppo city and transported to the reproductive biotechnology laboratory at Aleppo University (about $1 \mathrm{~h}$ ) in Dulbecco's PBS (DPBS). Cumulus oocyte complexes (COCs) were collected by the slicing method from follicles 3-8 mm. COCs with evenly granulated cytoplasm and with 3 or more layers of cumulus cells attached were selected for further work.

\section{In vitro maturation (IVM)}

COCs were matured as described previously by Salvador et al. (2011) with some modifications. COCs were washed three times in phosphate buffer saline solution (PBS) supplemented with $50 \mu \mathrm{g} / \mathrm{ml}$ gentamicin, and cultured in 50- $\mu 1$ microdrop of maturation medium (TCM-199) supplemented with $0.255 \mathrm{mM}$ sodium pyruvate, $10 \%$ heat-treated estrus cow serum, $5 \mu \mathrm{g} / \mathrm{ml} \mathrm{FSH,} 25 \mathrm{mM}$ Hepes and $100 \mu \mathrm{M}$ cysteamine and incubated under paraffin oil for $27 \mathrm{~h}$ at $39{ }^{\circ} \mathrm{C}$ in a humidified atmosphere of $5 \% \mathrm{CO}_{2}$ in the air for 27 hours.

\section{Sperm preparation and in vitro fertilization (IVF)}

Following maturation, presumptive $\mathrm{COCs}$ were denuded of surrounding cumulus cells by vortexing for $1 \mathrm{~min}$ in $2 \mathrm{ml}$ HEPES-TALP and washed three times in HEPES-TALP supplemented with $2 \%$ bovine serum albumin (BSA) and twice in IVF-TALP. Oocytes were transferred into four-well plates containing $250 \mu \mathrm{l}$ of Fertil-TALP. The fertilization medium (TALP) was supplemented with a final concentration of $10 \mu \mathrm{g} / \mathrm{ml}$ heparin-sodium salt, $500 \mu \mathrm{M}$ epinephrine, and $250 \mu \mathrm{M}$ penicillamine. Frozen-thawed Awassi ram semen was prepared for IVF using previously described methods by Salvador et al. (2011) with some modifications. Briefly, two frozen semen straws were thawed in a water bath at $38{ }^{\circ} \mathrm{C}$ for 30 seconds and emptied in a centrifuge tube with $4 \mathrm{ml}$ of Hepes-TALP medium. The tube was centrifuged at $200 \mathrm{x} \mathrm{g}$ for 10 minutes. The resulting aliquot of sperm pellet was resuspended (1:1) with the Hepes-TALP medium. Then $2 \mathrm{ml}$ of HepesTALP medium was added to $50 \mu$ of aliquots of spermatozoa and placed at the bottom of a conical tube for Swim-up. After $1 \mathrm{~h}, 0.5 \mathrm{ml}$ of the sperm suspension was collected from the upper part of the tube and centrifuged at $200 \mathrm{x} \mathrm{g}$ for $10 \mathrm{~min}$. The resulting sperm pellet was resuspended with heparin containing (100 $\mu \mathrm{g} / \mathrm{ml}$ ) Hepes-TALP medium and incubated for $45 \mathrm{~min}$ at $38.5{ }^{\circ} \mathrm{C}$. The sperm concentration was assessed in a hemocytometer and the sperm pellet was resuspended in TALP to give a final concentration of $3 \times 10^{9}$ sperms $/ \mathrm{ml}$. The sperm suspension was added to each fertilization well to obtain a final concentration of $1.5 \times 10^{6}$ spermatozoa/ml. Plates were incubated for $17 \mathrm{~h}$ under $5 \% \quad \mathrm{CO}_{2}$ in the air with maximum humidity $(>95 \%)$ at $38.5^{\circ} \mathrm{C}$. Resulting zygotes were rinsed with PBS and examined under an inverted microscope to detect second polar body formation.

\section{In vitro culture}

Following IVF, presumptive zygotes were gently vortexed in PBS to remove spermatozoa or cumulus cells remaining attached to these zygotes. All zygotes were washed twice in PBS and the same in TCM-199 before being transferred into the culture wells. Zygotes were Cultured in TCM-199 under mineral oil in a humidified atmosphere of $5 \% \mathrm{CO}_{2}, 5 \% \mathrm{O}_{2}$, and $90 \% \mathrm{~N}_{2}$ at $38.5{ }^{\circ} \mathrm{C}$. Fetal calf serum (FCS, $10 \%$ ) was added $24 \mathrm{~h}$ for six days (Silva et al. 2010). 
Table 1. Volumes of DMSO and EG used in vitrification of Awassi sheep embryos (ml)

\begin{tabular}{lccccccc}
\hline & \multicolumn{9}{c}{ Solution } \\
\cline { 2 - 8 } Cryoprotectant & \multicolumn{3}{c}{$\mathrm{A}$} & \multicolumn{2}{c}{ B } & \multicolumn{2}{c}{ C } \\
\cline { 2 - 8 } & $\mathrm{VS}^{*}$ & $\mathrm{ES}^{* *}$ & VS & ES & VS & ES \\
\hline DMSO & 3 & 1.5 & - & - & 1.5 & 0.75 \\
EG & - & - & 3 & 1.5 & 1.5 & 0.75 \\
\hline
\end{tabular}

$\mathrm{VS}^{*}$ : Vitrification solution, ES ${ }^{* *}$ : Equilibrium solution

\section{Embryos cryopreservation}

The resulting embryos were vitrified as described previously by Ghorbani et al. (2012), with some modifications. Briefly, both of vitrification solution (VS) and equilibrium solution (ES) comprised of TCM199 culture media supplemented with $0.4 \%$ calf serum (CS) and different volumes (ml) of the cryoprotectants dimethyl sulphoxide (DMSO), ethylene glycol (EG) and combination of DMSO and EG 1:1 divided into three solutions A, B, and C, each solution contained two parts: VS and ES as it is shown in Table 1. TCM-199 culture media was added to both VS and ES solutions, while only $0.5 \mathrm{M}$ sucrose was added to ES solution, to give a final volume of $10 \mathrm{ml}$ for each solution. Embryos were treated to vitrification by putting them in ES solution for 8 minutes at moderate room temperature (stage 1) and transferred to VS solutions for 1 minute exactly (stage 2 ), during that time (1 minute) every 6 embryos were put in straw $(0.25 \mathrm{~mm})$ and closed well by special devices and plunged immediately in liquid nitrogen. Embryos were left in liquid nitrogen for three days (72 hours).

\section{Embryos thawing, culture and survivability determination}

Frozen embryos were thawed across two steps as described previously by Ghorbani et al. (2012) with some modifications as follows: Cryoprotectant was removed by transferring the embryos in two successive baths containing decreasing concentrations of sucrose and a fixed concentration of calf serum (CS): $20 \%$ calf serum +1 M sucrose; 20\% CS+0.5 M sucrose supplemented with TCM-199 culture media to give a final volume of $10 \mathrm{ml}$. Embryos were placed into the first solution at room temperature $\left(22-25^{\circ} \mathrm{C}\right)$ for $1 \mathrm{~min}$, then placed into the second solution for $3 \mathrm{~min}$, before they were placed in TCM-199 culture media for an additional $5 \mathrm{~min}$. Embryos were then cultured in $500 \mathrm{ml}$ of TCM-199 at $38.8{ }^{\circ} \mathrm{C}$, in presence of $5 \% \mathrm{CO}_{2}, 5 \% \mathrm{O}_{2}$ and $90 \% \mathrm{~N}_{2}$ at $100 \%$ humidity. Embryos survivability were identified after freezing depending on the increase in the number of cells in early embryos (2-16 cell), morulae and blastocyst were identified depending on the subsequent development depending on the reexpansion of the embryos sizes and by the increase in the outer diameter and the arrival of to the hatching blastocyst stage.

\section{Embryo grading}

Embryos were graded according to their quality (exterior shape) into three main groups based on the classification of Wintner et al. (2017) with some modification as follows:

- Type 1: Cells are of equal size; no fragmentation is seen.

- Type 2: Cells are of equal size; minor fragmentation only.

- Type 3: Cells are of equal or unequal size; fragmentation is moderate to heavy.

\section{Reagents}

The chemicals used were from Sigma Chemical Co (St. Louis, USA) unless mentioned otherwise.

\section{Statistical analysis}

The experiment was designed according to the single-factor experimental design for several traits. Pearson Chi-square of contingency table and exact Fisher test were used to analyze the data among groups of vitrification cryoprotectants solutions for different stages of survived embryos using SAS, 14.3 Software package (SAS Institute 2017).

\section{RESULTS AND DISCUSSION}

\section{Result}

\section{Survivability and development of embryos following vitrification}

Our results show that the total rates of survived Awassi sheep embryos in different stages of embryonic development vitrified in C solution which composed of a combination of DMSO and EG cryoprotectants was 
greater $(\mathrm{P}<0.01)$ compared to those vitrified in the tow solutions A and B (vitrified by using single type DMSO or EG): $76.3 \%$ versus $44.1 \%$ and $42.4 \%$ respectively. The survival rates of blastocyst and hatching blastocyst for vitrified embryos in $\mathrm{C}$ solution was high $(\mathrm{P}<0.05)$ compared to those vitrified in the two solutions $\mathrm{A}$ and B: $92.8 \%$ versus $58.3 \%$ and $50 \%$ respectively. Moreover, the survival rate of vitrified embryos reaching to morulae stage in $\mathrm{C}$ solution was superior $(\mathrm{P}<0.05)$ compared to those vitrified in both solutions A and B: $90 \%$ versus $44.4 \%$ and $40 \%$ respectively. Although the survival rate of 2-16 cell stage embryos vitrified in $\mathrm{C}$ solution was slightly greater compared to those vitrified in the two solutions $\mathrm{A}$ and $\mathrm{B}: 50 \%$ versus $30.8 \%$ and $36.4 \%$ respectively, but these differences were not significant (Table 2).

In detail, as shown in Table 3, total rates of cleavages differed significantly $(\mathrm{P}<0.01)$ through the various stages of embryonic development where the embryos vitrified in $\mathrm{C}$ solution attained higher values: $50.0 \%, 90.0 \%$, and $92.9 \%$, respectively, the rates of embryos reached to blastocyst and hatching blastocyst stages increased significantly $(\mathrm{P}<0.01)$ from $2-16$ cell to blastocyst stage across the three solutions $\mathrm{A}, \mathrm{B}$ and $\mathrm{C}$, it should be noted that these rates were high and doubled for embryos that were subjected to $\mathrm{C}$ solution $(39.20 \%, 85.00 \%$ and $89.29 \%$ for $2-16$ cell, morula and blastocyst stage respectively).

\section{Lyses and arrest of embryos}

The rates of arrested embryos generally converged $(\mathrm{P}<0.05)$ in $2-16$ cell stage embryos across the three solutions $\mathrm{A}, \mathrm{B}$ and $\mathrm{C}$ while these rates were virtually zero in the morula and blastocyst stages for embryos that were subjected to $\mathrm{C}$ solution $(0.00$ and $3.70 \%$ respectively) (Table 4). Rates of lyses were completely absent at morula and blastocyst stage embryos that were vitrified in $\mathrm{C}$ solution. It was also observed a low rate of lyses of embryos that were vitrified in a single solution
(A and B solutions) (Table 4). The general difference between these rates was $20 \%$, noting that there was no significant difference among these rates.

\section{Embryo quality}

There were no significant differences in the quality of developed embryos after thawing despite the high rates of Type 3 embryos in 2-16 cell stage embryos across the three solutions A, B, and C: $75.0 \%, 75.0 \%$, and $80.0 \%$, respectively (Table 5).

\section{Discussion}

Vitrification is considered a modern, potential, important, and essential method that has replaced the traditional freezing methods, especially the slow freezing (Moussa et al. 2014). Its advantages include reducing the cost of freezing, speed, and simplicity of the application as well as its effective use on oocytes, sperm, ovaries, and cellular tissues (Chen \& Yang 2009).

In general, our results (Table 2) came close with many of the studies that have confirmed the possibility of using different types of cryoprotectants in vitrification method in many species such as in mice embryos (Momozawa et al. 2017), and cows (Caamaño et al. 2015). Moreover, the survival rates of the embryos in the current study are in agreement with the result of Riha \& Vejnar (2004) who observed a very high survival rate $(80 \%)$ of embryos vitrified in solution composed of $25 \% \mathrm{v} / \mathrm{v}$ EG $+25 \%$ v/v DMSO in culture medium supplemented with $20 \% \mathrm{v} / \mathrm{v}$ of FCS. While current results are slightly greater than the results of Donnay et al. (1998) who observed a high rate $(67 \%)$ of In vitro development in embryos vitrified in solution composed of $25 \% \mathrm{v} / \mathrm{v} \mathrm{EG}+25 \% \mathrm{v} / \mathrm{v} \mathrm{G}$.

The survival rates of both morulae and blastocyst stages vitrified in $\mathrm{C}$ solution are higher than those

Table 2. Total rates of survival and development of vitrified Awassi sheep embryos following thawing-culturing in vitro

\begin{tabular}{|c|c|c|c|c|c|c|c|c|}
\hline \multirow{3}{*}{$\begin{array}{l}\text { Cryoprotectants } \\
\text { solutions* }\end{array}$} & \multicolumn{6}{|c|}{ Stages of embryos } & \multirow{2}{*}{\multicolumn{2}{|c|}{$\begin{array}{c}\text { Total rates of survived } \\
\text { embryos }\end{array}$}} \\
\hline & \multicolumn{2}{|c|}{ 2- 16 cell } & \multicolumn{2}{|c|}{ Morulae } & \multicolumn{2}{|c|}{$\begin{array}{l}\text { Blastocyst } \\
\text { and hatching blastocyst }\end{array}$} & & \\
\hline & No. & $\%$ & No. & $\%$ & No. & $\%$ & No. & $\%$ \\
\hline A & 8 & 30.76 & 8 & $44.44^{\mathrm{a}}$ & 14 & $58.33^{\mathrm{a}}$ & 30 & $44.11^{\mathrm{a}}$ \\
\hline B & 8 & 36.36 & 8 & $40.00^{\mathrm{a}}$ & 12 & $50.00^{\mathrm{a}}$ & 28 & $42.42^{\mathrm{a}}$ \\
\hline $\mathrm{C}$ & 14 & 50.00 & 18 & $90.00^{\mathrm{b}}$ & 26 & $92.85^{\mathrm{b}}$ & 58 & $76.31^{\mathrm{b}}$ \\
\hline Sig & & $\mathrm{NS}^{1}$ & & $\begin{array}{l}\mathrm{P}< \\
0.05\end{array}$ & & $\mathrm{P}<0.05$ & & $\mathrm{P}<0.01$ \\
\hline
\end{tabular}

Values with different subscripts (a and b) differ within column at assigned probability

NS1: not significant; A: DMSO, B: EG, C: DMSO+EG 
Table 3. In vitro development of various stages of Awassi sheep embryos following verification

\begin{tabular}{|c|c|c|c|c|c|c|}
\hline $\begin{array}{l}\text { Developmental } \\
\text { stage }\end{array}$ & $\begin{array}{c}\text { Vitrification } \\
\text { solution* }\end{array}$ & $\begin{array}{l}\text { Vitrified } \\
\text { (No.) }\end{array}$ & $\begin{array}{l}\text { Recovered } \\
(\%)\end{array}$ & $\begin{array}{c}\text { Morphologically } \\
\text { normal } \\
(\%)\end{array}$ & $\begin{array}{c}\text { Cleavages } \\
(\%)\end{array}$ & $\begin{array}{l}\text { Blastocyst and } \\
\text { hatching } \\
\text { blastocyst } \\
(\%)\end{array}$ \\
\hline \multirow{3}{*}{$2-16$ cell } & A & 26 & $57.69(15 / 26)^{\mathrm{a}}$ & $50.00(13 / 26)^{\mathrm{a}}$ & $30.77(8 / 26)^{\mathrm{a}}$ & $23.08(6 / 26)^{\mathrm{a}}$ \\
\hline & B & 22 & $63.64(14 / 22)^{\mathrm{a}, \mathrm{b}}$ & $54.55(12 / 22)^{\mathrm{a}}$ & $36.36(8 / 22)^{\mathrm{a}, \mathrm{b}}$ & $22.73(5 / 22)^{a, b}$ \\
\hline & $\mathrm{C}$ & 28 & $78.57(22 / 28)^{a, b, c}$ & $64.29(18 / 28)^{\mathrm{a}, \mathrm{b}}$ & $50.00(14 / 28)^{\mathrm{a}, \mathrm{b}}$ & $39.20(11 / 28)^{\mathrm{a}, \mathrm{b}}$ \\
\hline \multirow{3}{*}{ Morula } & A & 18 & $88.89(16 / 18)^{\mathrm{b}, \mathrm{c}, \mathrm{d}}$ & $77.78(14 / 18)^{\mathrm{a}, \mathrm{b}, \mathrm{c}}$ & $44.44(8 / 18)^{\mathrm{a}, \mathrm{b}}$ & $44.44(8 / 18)^{\mathrm{a}, \mathrm{b}}$ \\
\hline & B & 20 & $90.00(18 / 20)^{\mathrm{c}, \mathrm{d}}$ & $75.00(15 / 20)^{\mathrm{a}, \mathrm{b}, \mathrm{c}}$ & $40.00(8 / 20)^{\mathrm{a}, \mathrm{b}}$ & $35.00(7 / 20)^{\mathrm{a}, \mathrm{b}}$ \\
\hline & $\mathrm{C}$ & 20 & $90.00(18 / 20)^{\mathrm{c}, \mathrm{d}}$ & $90.00(18 / 20)^{c}$ & $90.00(18 / 20)^{c}$ & $85.00(17 / 20)^{c}$ \\
\hline \multirow{3}{*}{ Blastocyst } & A & 24 & $95.83(23 / 24)^{\mathrm{c}, \mathrm{d}}$ & $91.67(22 / 24)^{c}$ & $58.33(14 / 24)^{b}$ & $50.00(12 / 24)^{b}$ \\
\hline & B & 24 & $91.67(22 / 24)^{\mathrm{c}, \mathrm{d}}$ & $83.33(20 / 24)^{b, c}$ & $50.00(12 / 24)^{\mathrm{a}, \mathrm{b}}$ & $45.83(11 / 24)^{\mathrm{a}, \mathrm{b}}$ \\
\hline & $\mathrm{C}$ & 28 & $96.43(27 / 28)^{\mathrm{d}}$ & $92.86(26 / 28)^{c}$ & $92.86(26 / 28)^{c}$ & $89.29(25 / 28)^{c}$ \\
\hline Sig & & & $\mathrm{P}<0.01$ & $\mathrm{P}<0.05$ & $\mathrm{P}<0.01$ & $\mathrm{P}<0.01$ \\
\hline
\end{tabular}

Values with different subscripts (a, b, c and d) differ within column at assigned probability

A: DMSO, B: EG, C: DMSO+EG

Table 4. Rates of lyses and arrest of embryos following thawing of various developmental stages of Awassi sheep embryos in vitro.

\begin{tabular}{lcccc}
\hline \hline Developmental stage & $\begin{array}{c}\text { Vitrification } \\
\text { solution* }\end{array}$ & $\begin{array}{c}\text { Vitrified } \\
(\text { No. })\end{array}$ & $\begin{array}{c}\text { Lyses } \\
(\%)\end{array}$ & $\begin{array}{c}\text { Arrested } \\
(\%)\end{array}$ \\
\hline 2-16 cell & A & 26 & $20.00(3 / 15)$ & $26.67(4 / 15)^{\mathrm{a}}$ \\
& B & 22 & $14.29(2 / 14)$ & $28.57(4 / 14)^{\mathrm{a}}$ \\
& C & 28 & $13.64(3 / 22)$ & $22.73(5 / 22)^{\mathrm{a}, \mathrm{b}}$ \\
Morula & A & 18 & $12.50(2 / 16)$ & $37.50(6 / 16)^{\mathrm{a}, \mathrm{b}, \mathrm{c}}$ \\
& B & 20 & $11.11(2 / 18)$ & $44.44(8 / 18)^{\mathrm{a}, \mathrm{b}, \mathrm{c}}$ \\
Blastocyst & C & 20 & $0.00(0 / 18)$ & $0.00(0 / 18)^{\mathrm{c}}$ \\
& A & 24 & $8.70(2 / 23)$ & $30.43(7 / 23)^{\mathrm{c}}$ \\
Sig & B & 24 & $9.09(2 / 22)$ & $36.36(8 / 22)^{\mathrm{b}, \mathrm{c}}$ \\
\hline Values with different subscripts (a, b and c) differ within column at assigned probability & $0.00(0 / 27)$ & $3.70(1 / 27)^{\mathrm{c}}$
\end{tabular}

Values with different subscripts $(\mathrm{a}, \mathrm{b}$ and $\mathrm{c}$ ) differ within column at assigned probability NS: not significant. A: DMSO, B: EG, C: DMSO+EG 
Table 5. Rates of embryo quality types following of various developmental stages of Awassi sheep embryos in vitro

\begin{tabular}{|c|c|c|c|c|}
\hline \multirow{2}{*}{$\begin{array}{l}\text { Developmental } \\
\text { stage }\end{array}$} & \multirow{2}{*}{ Vitrification solution* } & \multicolumn{3}{|c|}{ Embryo quality } \\
\hline & & Type $1(\%)$ & Type $2(\%)$ & Type $3(\%)$ \\
\hline \multirow{3}{*}{$2-16$ cell } & A & $0.00(0 / 4)$ & $25.00(1 / 4)$ & $75.00(3 / 4)$ \\
\hline & B & $0.00(0 / 4)$ & $25.00(1 / 4)$ & $75.00(3 / 4)$ \\
\hline & $\mathrm{C}$ & $20.00(1 / 5)$ & $0.00(0 / 5)$ & $80.00(4 / 5)$ \\
\hline \multirow{3}{*}{ Morula } & A & $16.67(1 / 7)$ & $33.33(2 / 6)$ & $50.00(3 / 6)$ \\
\hline & B & $25.00(2 / 8)$ & $37.50(3 / 8)$ & $37.50(3 / 8)$ \\
\hline & $\mathrm{C}$ & $0.00(0 / 0)$ & $0.00(0 / 0)$ & $0.00(0 / 0)$ \\
\hline \multirow{3}{*}{ Blastocyst } & A & $14.29(1 / 7)$ & $42.86(3 / 7)$ & $42.86(3 / 7)$ \\
\hline & $\mathrm{B}$ & $25.00(2 / 8)$ & $37.50(3 / 8)$ & $37.50(3 / 8)$ \\
\hline & $\mathrm{C}$ & $0.00(0 / 1)$ & $100(1 / 1)$ & $0.00(0 / 1)$ \\
\hline Sig & & $\mathrm{NS}^{1}$ & NS & NS \\
\hline
\end{tabular}

$\mathrm{NS}^{1}:$ not significant

A: DMSO, B: EG, C: DMSO+EG

obtained by Gibbons et al. (2011) where survival rates of same two stages in goats were $41 \%$ and $50 \%$ respectively, and in sheep $64 \%$ and $64 \%$ respectively.

As evidenced in Tables 2, 3, differences were observed $(\mathrm{P}<0.01)$ among the rates of morulae and blastocyst stages vitrified in $\mathrm{C}$ solution compared with those vitrified in the tow solutions $\mathrm{A}$ and $\mathrm{B}$ indicating that using a combination of two types of cryoprotectants in vitrification helps improving embryos survivability in many stages compared to single type usage. As a result, the solidarity effect of the cryoprotectants reduces the toxicity levels in frozen embryos. Also, current results were less than the rates reached by Bagis et al. (2005) for the same solution (C solution) but with different concentrations of DMSO and EG, the values were $79 \%$, and $43 \%$, respectively, as well as the rate of the resulting morulae in B solution, came less than the same obtained by Bagis et al. (2005) by using EG in vitrification (69\% and 52\% respectively). Shirazi et al. (2010) found differences $(\mathrm{P}<0.01)$ in survival rates of morulae and blastocyst stages compared to $2-16$ cell stage embryos in tow vitrification solutions (3.4M G + 4.8M EG and 2.7M G, + 3.4 M DMSO). As for the influence of cryoprotectants on embryos survivability of 2-16 cell stage embryos, our results showed that survival rates of embryos vitrified in the three solutions A, B, and C was higher than those obtained by Martínez et al. (2006) where survival rates were less than $10 \%$, as well as the current results, were higher than the results obtained by Han et al. (2000) which not exceeded $20 \%$. However, the current results of the 2-16 cell stage are considered encouraging because of the importance of this stage in recent embryo technology applications, and because of the rarity in studies interested in this stage of embryonic development. These differences in the former results due to the influence of the types of cryoprotectants, the way of adding them (single or contributor), and to the solidarity effect of cryoprotectants (Leibo \& Pool 2011). The differences, also, can be attributed to developmental stage and the content of lipid of frozen embryos, Gajda et al. (2011) found a slight difference among the survival rates at different stages of embryonic development, where the rates rose at morulae and blastocyst stages which they usually characterized by a decrease in the level of lipids in their cells. Also, the length of exposing embryos period to ES and VS solutions affects the survival rates of embryos before freezing (Păcală et al. 2012). In our study, the survival rates of 2-16 cell stage embryos came low compared with those in morulae and blastocyst on the one hand and low survival rates of morulae compared to blastocyst on the other hand, this, can be explained to the difference in size of the embryonic cells in different stages of development. Tachikawa et al. (1993) noted that the large size of the cells in 2-16 cell stage makes them more sensitive to the stresses of osmotic pressure and toxicity of cryoprotectants during penetrating cell embryos unlike morulae and blastocyst which characterized by the small size of their cells compared to 2-16 cell stage embryos, and thus, survival rates in blastocyst were high compared to those in the earlier stages of embryonic development.

In the current study, despite the insignificance, rates of lysed embryos came high in blastomere embryos comparing to morula and blastocyst stages (Table 4), in 
literature, many studies referred that the cryodamage in morulae and blastocyst stage is higher than in the blastomeres (Gupta \& Lee 2010). Balaban et al. (2008) noted that the cryodamage may affect negatively at various cooling rates by causing a perturbation in metabolism.

Absence of significance in the quality of the embryos was clarified despite the high rates of embryos of Type 3 of 2-16 cell stage embryos in the current study (Table 5), it seems that the factors that control the quality of embryos produced in vitro are many and a bit complicated, but the most important factor that can justify the absence of differences in the quality of embryos in most studies is the physiological and reproductive status of the animal in the period immediately preceding slaughter. Santos et al. (2008) attributed the low quality of embryos and oocytes to the effects of negative energy balance.

\section{CONCLUSION}

It concluded from this study that using a combination of the cryoprotectants DMSO and EG in vitrification led to high survival rates of embryos compared to those vitrified in single type (DMSO or EG). Also, the vitrification of 2-16 cell stage embryos in the same solution led to encouraging rates of survivability despite the slightness in rates values.

\section{REFERENCES}

Arav A. 2014. Cryopreservation of oocytes and embryos. Theriogenology. 81:96-102.

Bagis H, Mercan HO, Cetin S, Sekmen S. 2005. The effect of equilibration time on survival and development rates of mouse pronuclear-stage embryos vitrified in solid surface (SSV) and convential straws: In vitro and In vivo evaluations. Mol Reprod Dev. 72:494-501.

Balaban B, Urman B, Ata B, Isiklar A, Larman MG, Hamilton R, Gardner DK. 2008. A randomized controlled study of human Day 3 embryo cryopreservation by slow freezing or vitrification: vitrification is associated with higher survival, metabolism and blastocyst formation. Hum Reprod. 23:1976-1982.

Best BP. 2015. Cryoprotectant Toxicity: Facts, Issues, and Questions. Rejuvenation Res. 18:422-436.

Bhattacharya S. 2018. Cryopretectants and Their Usage in Cryopreservation Process. In: Cryopreserv Biotechnol Biomed Biol Sci. London (UK): IntechOpen.

Bromfield JJ, Coticchio G, Hutt K, Sciajno R, Borini A, Albertini DF. 2009. Meiotic spindle dynamics in human oocytes following slow-cooling cryopreservation. Hum Reprod. 24:2114-2123.
Caamaño JN, Gómez E, Trigal B, Muñoz M, Carrocera S, Martín D, Díez C. 2015. Survival of vitrified in vitroproduced bovine embryos after a one-step warming instraw cryoprotectant dilution procedure. Theriogenology. 83:881-890.

Chen S-U, Yang Y-S. 2009. Slow freezing or vitrification of oocytes: their effects on survival and meiotic spindles, and the time schedule for clinical practice. Taiwan $\mathbf{J}$ Obstet Gynecol. 48:15-22.

Donnay I, Auquier P, Kaidi S, Carolan C, Lonergan P, Mermillod P, Massip A. 1998. Vitrification of in vitro produced bovine blastocysts: methodological studies and developmental capacity. Anim Reprod Sci. 52:93104.

Fahy GM. 2010. Cryoprotectant toxicity neutralization. Cryobiology. 60:S45-S53.

Gajda B, Romek M, Grad I, Krzysztofowicz E, Bryla M, Smorag Z. 2011. Lipid content and cryotolerance of porcine embryos cultured with phenazine ethosulfate. CryoLetters. 32:349-357.

Ghorbani M, Sadrkhanlou R, Nejati V, Ahmadi A, Tizroo G. 2012. The effects of dimethyl sulfoxide and ethylene glycol as vitrification protectants on different cleavage stages of mouse embryo quality. Vet Res forum an Int Q J. 3:245-9.

Gibbons A, Cueto MI, Pereyra Bonnet F. 2011. A simple vitrification technique for sheep and goat embryo cryopreservation. Small Rumin Res. 95:61-64.

Gupta M, Lee H. 2010. Cryopreservation of Oocytes and Embryos by Vitrification. Clin Exp Reprod Med. 37:267-291.

Han YM, Kim SJ, Park JS, Park IY, Kang YK, Lee CS, Koo DB, Lee TH, Yu DY, Kim YH, Lee KJ, Lee KK. 2000. Blastocyst viability and generation of transgenic cattle following freezing of in vitro produced, DNA-injected embryos. Anim Reprod Sci. 63:53-63.

Leibo SP, Pool TB. 2011. The principal variables of cryopreservation: solutions, temperatures, and rate changes. Fertil Steril. 96:269-276.

Martínez AG, Valcárcel A, Furnus CC, de Matos DG, Iorio G, de las Heras MA. 2006. Cryopreservation of in vitroproduced ovine embryos. Small Rumin Res. 63:288296.

Momozawa K, Matsuzawa A, Tokunaga Y, Abe S, Koyanagi Y, Kurita M, Nakano M, Miyake T. 2017. Efficient vitrification of mouse embryos using the Kitasato Vitrification System as a novel vitrification device. Reprod Biol Endocrinol. 15:29.

Moussa M, Shu J, Zhang X, Zeng F. 2014. Cryopreservation of mammalian oocytes and embryos: current problems and future perspectives. Sci China Life Sci. 57:903-914.

Păcală N, Ivan A, Cean A. 2012. Vitrification of mice embryos in different developmental stages using four 
vitrification methods. Biotechnol Biotechnol Equip. $26: 3324-3328$

Palasz AT, Breña PB, Martinez MF, Perez-Garnelo SS, Ramirez MA, Gutiérrez-Adán A, De la Fuente J. 2008. Development, molecular composition and freeze tolerance of bovine embryos cultured in TCM-199 supplemented with hyaluronan. Zygote. 16:39-47.

Riha J, Vejnar J. 2004. Comparison of two vitrification methods for cryopreservation of porcine embryos. Czech J Anim Sci. 49:183-189.

Salvador I, Cebrian-Serrano A, Salamone D, Silvestre M. 2011. Effect of number of oocytes and embryos on in vitro oocyte maturation, fertilization and embryo development in bovine. Spanish J Agric Res. 9:744752 .

Santos JEP, Cerri RLA, Sartori R. 2008. Nutritional management of the donor cow. Theriogenology. 69:8897.

SAS Institute. 2017. SAS/STAT® 14.3 User's Guide. Cary, NC 27513 (USA): SAS Institute.
Shirazi A, Soleimani M, Karimi M, Nazari H, Ahmadi E, Heidari B. 2010. Vitrification of in vitro produced ovine embryos at various developmental stages using two methods. Cryobiology. 60:204-210.

Silva D, Pereira, LPNavarro R, Rosa D, Pessoa G, Silva C, Rubin M. 2010. in vitro production of Bos taurus indicus embryos with cysteamine. Anim Reprod. 7:2934 .

Tachikawa S, Otoi T, Kondo S, Machida T, Kasai M. 1993. Successful vitrification of bovine blastocysts, derived by in vitro maturation and fertilization. Mol Reprod Dev. 34:266-271.

Thompson M, Nemits M, Ehrhardt R. 2011. Rate-controlled cryopreservation and thawing of mammalian cells. Protoc Exch.

Wintner EM, Hershko-Klement A, Tzadikevitch K, Ghetler Y, Gonen O, Wintner O, Shulman A, Wiser A. 2017. Does the transfer of a poor quality embryo together with a good quality embryo affect the In Vitro Fertilization (IVF) outcome? J Ovarian Res. 10:2. 